\title{
Analysis on the Bullying Tendencies and Value Preferences of High School Students According To Level of Receiving Physical Education and Sports Course
}

\author{
Yüksel Savucu ${ }^{1}$, Metin Kanat ${ }^{2}$, Mustafa Karadağ ${ }^{1}$, Süreyya. Y. Sezer ${ }^{1} \&$ Ali S. Yücel $^{1}$ \\ ${ }^{1}$ Faculty of Sports Sciences, Firat University, Turkey \\ ${ }^{2}$ School of Malatya, Turkey \\ Correspondence: Yüksel Savucu, Faculty of Sports Sciences, Firat University, Elazig, Turkey. Tel: \\ 9-424-241-6511. E-mail: ysavucu@hotmail.com
}

$\begin{array}{lc}\text { Received: February 7, } 2017 & \text { Accepted: March 12, } 2017 \quad \text { Online Published: June 27, } 2017 \\ \text { doi:10.5539/ies.v10n7p40 } & \text { URL: https://doi.org/10.5539/ies.v10n7p40 }\end{array}$

\begin{abstract}
The aim of this study was to investigate the bullying tendencies and value preferences of high school students according to the level of taking physical education and sports course.

The research population of the study was composed of high school students studying in Yeşilyurt and Battalgazi districts of Malatya province during 2013-2014 academic year. Sample stratified sampling method was used in the sample selection. In order to collect the necessary data for the research, Personal Information Form, Schwartz Portrait Values Survey and Bullying Tendencies Scale were used.

In the study, the distribution of the scores belonging to dependent variables at the pores of the subunits of the independent variables was analyzed in terms of the assumptions of normality. In the analysis process, non-parametric statistical methods were preferred. For this purpose, data were tested in accordance with the sub-problems of the research using descriptive analysis (mean and standard deviation) and non-parametric analysis such as Mann-Whitney U test and Kruskal Wallis H test. In analysis of the data, statistical package software program was used and the significance level of $p<.05$ was taken.

A significant level of difference was found between total value scores of students according to their classes and the number physical education and sports courses taken by those students. A significant level of difference was found between total bullying tendency scores of students by their genders, the number physical education and sports courses taken by those students and the students' family income. A significant level of difference was found between total bullying tendency scores of students by the type of schools they attend. A significant level of difference was found between total value scores of students according to the type of schools they attend. A moderate negative relationship was found between the total value scores and total bullying tendency scores of students. Accordingly, as the total value scores of student increase, their bullying tendency scores decrease.
\end{abstract}

Keywords: basic values, student, bullying tendencies, physical education and sports

\section{Introduction}

The concept of value is used by many scientific fields such as economics, philosophy, sociology, psychology and theology. The fact that it is used by different scientific fields has caused different definition of the concept of value. The mostly emphasized notions while making value definitions are tendencies, beliefs, normative standards and purposes. It is necessary to allow for other definitions instead of reaching to only one definition related valuing (Dilmaç et al., 2008). While Rokeach conducting many systematic researches about values defines value as a permanent belief (Rokeach, 1970); Fichter and Tezcan are of the opinion that values are shared, most people reconcile on values. They don't depend on any judgment (Fichter, 2011; Tezcan, 1987).

Bullying is the imperious behaviors exposed by the students and it affects their academic, emotional and social development and it makes them come across many problems in adulthood. The studies conducted in this subject were first initiated by Olweus in 1970s (Hilooğlu \& Önder, 2010). According to some researchers, bullying is considered as a relatively small problem; however, it refers to the type of behaviors that may lead to serious injuries and even death of the bully, victim or both (Genç, 2007). 
The most important problem encountered at schools all over the world is peer victimization that is ranked among the bullying at school. Tyrannical behaviors and that have become widespread at schools and their reasons have become the research subject of many educators and researchers. The school environment where a child starts socializing first after the family contributes to the social, emotional and cognitive development of an individual. Bullying at school results in social, emotional and academic problems of student. It is remarkable that according to the mostly used definition of bullying at school by experts, it refers to the negative actions continuously applied by one or more students to another student (Bektaş, 2007; Bilgiç, 2007; A. K. Kılıç \& A. Kılıç, 2013).

It is observed that the development of basic skills and values particularly in physical education courses is a long process. The purpose of the Physical Education Course Curriculum in Secondary Education is to help students realize many basic skills and values and to use them lifelong following four years (MEB, 2009). The purpose of our study was to analyze the bullying tendencies and value preferences of high school students according to the level of receiving physical education and sports course.

\section{Material and Method}

\subsection{Participant (Subject) Characteristics}

The research population is composed of a total of 613 students studying in Yeşilyurt and Battalgazi districts of Malatya province in 2013-2014 academic year (303 males and 310 females). 49.4\% of the participants are male and $50.6 \%$ is female. Personal Information Form, Schwartz Portrait Values Survey and Bullying Tendencies Scale were used in order to collect data required for this study (Schwartz, 2009; Demirutku and Sümer, 2010).

\subsection{Research Design}

Schwartz Portrait Values Survey: It is composed of 40 items each of them is composed of two sentences defining the targets and desires of hypothetical individuals and indirectly measuring the values belonging to different types of values. The pellucidity levels of the items were simplified as to the age level of 11 while developing these items. The respondents specify to what extent the individuals defined in each item resemble them by circling the appropriate box in a sub-dimensional rating scale according to the labels - each of them corresponds to different level of resemblance (It doesn't resemble me at all, It doesn't resemble me, It resembles me a bit, It resembles me a little, It resembles me, It resembles me a lot). Both Cronbach Alpha and test-retest reliability coefficients were calculated for the scales of value types created by the items of the survey (Demirutku \& Sümer, 2010).

Bullying Tendency Scale: This scale developed by Dölek is composed of the factors of Negative Reflection, Lack of Emotional Sharing, Justifying Bullying, Distressing, Using the Powerful and Not Being Disturbed (Dölek, 2002).

Data Analysis and Interpretation: Survey model was used in the research with the purpose of determining the bullying tendencies and value preferences of high school students. The distribution of the scores of dependent variables in the pores of the sub-units of independent variables was analyzed in terms of normality premise. Kolmogorov Simirnov, Shapiro-Wilk test results and the histogram with normal curve indicate that the distribution isn't normal. Non-parametric statistical methods were preferred in analyses. In this regard, data were tested by using the descriptive analyses (average and standard deviation) and Mann Whitney U test and Kuruskal Wallis $\mathrm{H}$ test being among the non-parametric analyses in line with the sub-problems of the research and the significance level was taken as $\mathrm{p}<.05$.

\section{Results}

Table 1. The distribution of students by their class

\begin{tabular}{lcc}
\hline & Frequency & $\%$ \\
\hline The $9^{\text {th }}$ Grade & 154 & 25.1 \\
The $10^{\text {th }}$ Grade & 154 & 25.1 \\
The $11^{\text {th }}$ Grade & 153 & 25.0 \\
The $12^{\text {th }}$ Grade & 152 & 24.8 \\
Total & 613 & 100.0 \\
\hline
\end{tabular}

$25.1 \%$ of the participants study in the $9^{\text {th }}$ grade, $25.1 \%$ studies in the $10^{\text {th }}$ grade, $25 \%$ studies in the $11^{\text {th }}$ grade and $24.8 \%$ of them study in the $12^{\text {th }}$ grade. 
Table 2. The distribution of students by the weekly course hours of physical education and sports

\begin{tabular}{lcc}
\hline & Frequency & $\%$ \\
\hline Not taking & 76 & 12.4 \\
1 hour & 42 & 6.9 \\
2 hours & 410 & 66.9 \\
4 hours & 30 & 4.9 \\
More than 6 hours & 55 & 9.0 \\
Total & 613 & 100.0 \\
\hline
\end{tabular}

$12.4 \%$ of the participants haven't taken any physical education and sports course, $6.9 \%$ of them takes this course for 1 hour, $66.9 \%$ takes this course for 2 hours, $4.9 \%$ takes this course for 4 hours and $9 \%$ takes this course more than 6 hours.

Table 3. The distribution of students by the educational background of their mothers

\begin{tabular}{lcc}
\hline & Frequency & $\%$ \\
\hline Illiterate & 60 & 9.8 \\
Literate & 39 & 6.4 \\
Primary School & 217 & 35.4 \\
Secondary School & 111 & 18.1 \\
High School & 112 & 18.3 \\
University & 63 & 10.3 \\
Postgraduate & 11 & 1.8 \\
Total & 613 & 100.0 \\
\hline
\end{tabular}

$9.8 \%$ of mothers of the participants are illiterate, $6.4 \%$ is literate, $35.4 \%$ is primary school graduate, $18.1 \%$ is secondary school graduate, $18.3 \%$ is high school graduate, $10.3 \%$ is university graduate and $1.8 \%$ is postgraduate.

Table 4. The distribution of students by the educational background of their fathers

\begin{tabular}{lcc}
\hline & Frequency & $\%$ \\
\hline Illiterate & 14 & 2.3 \\
Literate & 25 & 4.1 \\
Primary School & 153 & 25.0 \\
Secondary School & 133 & 21.7 \\
High School & 161 & 26.3 \\
University & 103 & 16.8 \\
Postgraduate & 24 & 3.9 \\
Total & 613 & 100.0 \\
\hline
\end{tabular}

$2.3 \%$ of fathers of the participants are illiterate, $4.1 \%$ is literate, $25 \%$ is primary school graduate, $21.7 \%$ is secondary school graduate, $26.3 \%$ is high school graduate, $16.8 \%$ is university graduate and $3.9 \%$ is postgraduate. 
Table 5. The distribution of students by the profession of their mothers

\begin{tabular}{lcc}
\hline & Frequency & $\%$ \\
\hline Housewife & 470 & 76.7 \\
Worker & 22 & 3.6 \\
Civil Servant & 66 & 10.8 \\
Day-Laborer & 29 & 4.7 \\
Retired & 12 & 2.0 \\
Other & 14 & 2.3 \\
Total & 613 & 100.0 \\
\hline
\end{tabular}

$76.7 \%$ of mothers of the participants are housewife, $3.6 \%$ is worker, $10.8 \%$ is civil servant, $4.7 \%$ is day laborer and $2 \%$ is retired and $2.3 \%$ is from other professions.

Table 6. The distribution of students by the profession of their fathers

\begin{tabular}{lcc}
\hline & Frequency & $\%$ \\
\hline Seasonal Worker & 41 & 6.7 \\
Worker & 167 & 27.2 \\
Civil Servant & 136 & 22.2 \\
Small Retailer & 65 & 10.6 \\
Retired & 83 & 13.5 \\
Other & 121 & 19.7 \\
Total & 613 & 100.0 \\
\hline
\end{tabular}

$6.7 \%$ of fathers of the participants are seasonal worker, $27.2 \%$ is worker, $22.2 \%$ is civil servant, $10.6 \%$ is small retailer, $13.5 \%$ is retired and $19.7 \%$ is from different occupations.

Table 7. The distribution of students by Turkish liras (TL) income level of their family

\begin{tabular}{lcc}
\hline & Frequency & $\%$ \\
\hline $0-500 \mathrm{TL}$ & 40 & 6.5 \\
$501-812 \mathrm{TL}$ & 123 & 20.1 \\
$813-1250 \mathrm{TL}$ & 151 & 24.6 \\
$1251-1750 \mathrm{TL}$ & 96 & 15.7 \\
$1751-2250 \mathrm{TL}$ & 51 & 8.3 \\
$2251-2500 \mathrm{TL}$ & 42 & 6.9 \\
2501 and more & 110 & 17.9 \\
Total & 613 & 100.0 \\
\hline
\end{tabular}

$6.5 \%$ of the participants' families earn 0-500 TL, 20.1\%earns 501-812 TL, $24.6 \%$ earns $813-1250 \mathrm{TL}, 15.7 \%$ earns $1251-1750 \mathrm{TL}, 8.3 \%$ earns $1751-2250 \mathrm{TL}, 6.9 \%$ earns $2251-2500 \mathrm{TL}$ and $17.9 \%$ earns $2501 \mathrm{TL}$ and more.

Table 8 . The distribution of students by the number of their siblings

\begin{tabular}{lcc}
\hline & Frequency & $\%$ \\
\hline None & 24 & 3.9 \\
One & 127 & 20.7 \\
Two & 146 & 23.8 \\
Three & 145 & 23.7 \\
Four and more & 171 & 27.9 \\
Total & 613 & 100.0 \\
\hline
\end{tabular}

$3.9 \%$ of the participants have no siblings, $20.7 \%$ has one, $23.8 \%$ has two, $23.7 \%$ has three and $27.9 \%$ has four and more siblings. 


\section{Discussion}

It is observed in our study that total value score didn't differ significantly by the sex of students [U=42941,50 $\mathrm{p}>.05]$. It can be uttered that female and male students attribute same meaning and importance to values equally. In a study supporting our findings, some results of the sub-dimensions of human values support our findings. They have also concluded in their study conducted on secondary school students that the attributes of emphatic tendencies and cooperation predict the human values and their average scores of friendship, being peaceful, honesty and respect that are considered among the human values don't differ significantly by sex. However, the average scores of female students concerning friendship, being peaceful, honesty and respect are higher than the average scores of male students (Dereli and Alpay).

In a post-graduate study titled as the comparison of the values of students exhibiting neurotic behaviors, it has been established that while the economic value ranks first in the male students aged between 20 and 24, esthetic value comes first in female students. According to the findings, while the lowest values in female students are religious and political values, esthetic and religious values come last for males (Özden, 2007).

A significant difference has been established between the total value scores of students concerning their classes they study. A significant difference has been found between the $9^{\text {th }}$ grade students and $10^{\text {th }}$ grade students and between the $11^{\text {th }}$ grade students and $12^{\text {th }}$ grade students.

There is a significant level of difference between the total value scores of students by the course hours of physical education and sports course. This significant difference is also observed between the students taking the physical education and sports course for 1 hour and those taking for 2 hours, 6 hours and more in favor of the students taking this course for 1 hour. This finding indicates that the students taking the physical education and sports course for 1 hour a week attribute more significance and importance to the values. In a study supporting our findings, it is observed that the value scores of students differ significantly by their class according to the findings obtained from a post-graduate thesis titled as the analysis on the perception of students studying in vocational high schools concerning career values (Güler, 2010).

It has been determined that the $11^{\text {th }}$ grade students express positive opinions more than the $10^{\text {th }}$ and $12^{\text {th }}$ grade students regarding the career value of "Autonomy/Independence". It is observed that the $12^{\text {th }}$ grade students perceive the career value of "Challenge" more positively than other student groups. It has been concluded that the $12^{\text {th }}$ grade students evaluate the career value of "Self-commitment" with higher points than the $11^{\text {th }}$ grade students. According to the results, the $12^{\text {th }}$ grade students evaluate the career value of "Lifestyle" with higher points than the $11^{\text {th }}$ grade students.

A significant difference hasn't been found between the total value scores of students by the educational background of their mothers. Calp (2006) hasn't found any significant difference between the religious views of students and their mothers' educational background according to the findings of the senior students studying at secondary school. In other words, the religious views of students don't differ by their mothers' educational background. In the same study, it can be stated that the scores of illiterate individuals regarding material values are lower than the scores of university graduates and this difference materializes in favor of the university graduates. Accordingly, it can be uttered that there is a significant relation between the educational background of students' mothers and their opinions regarding personal values (Calp, 2006).

The difference found between the total value scores of students by the educational background of the students' fathers, by the profession of their mothers and fathers weren't significant. In another study, the difference between the opinions of students on family values and the profession of their fathers isn't significant. In other words, the opinions of students about family values don't differ significantly by their fathers' profession (Calp, 2006).

There isn't a significant difference between the total value scores of students and the income of their families. There are studies supporting our findings in the literature. In a study analyzing the opinions of senior high school students concerning social values, it has been stated that there isn't a significant difference between the opinions of students on family and religious values and the income level of the family (Calp, 2006).

There isn't a significant difference found between the total value scores of students and the number of their siblings. However, there is a significant difference between the total bullying tendency scores of students by their sex. It has been observed that the bullying tendencies of male students are higher than the female students. In a similar study supporting our findings, it has been observed that boys apply bullying more than girls (Ayas and Pişkin, 2011). In other words, sex is a significant difference in terms of being both a bully and victim. In another research, it has been specified that male students perform tyrannous behaviors more than female students and 
they are exposed to these behaviors more (K1lıç \& Kılıç, 2013). According to Eşici (2013) coming to different results, the common effect of the sex of a total of 444 students 219 of them are boys and 225 of them are girls and the level of meeting their basic needs isn't significant on tyrannous behaviors (Eşici, 2013).

There isn't a significant difference between the total bullying tendency scores of students by the class they study. It has been stated that bullying tendency scores of the students studying in different classes are same. In a study conducted on the $2^{\text {nd }}$ grade students at primary school, it has been concluded that the rates of ranking at different statuses of bullying aren't significant by their class (Totan \& Kabakçı, 2010).

There is a significant difference between the total bullying tendency scores of students by the physical education and sports course hours. This significant difference is also observed between the students not taking the physical education and sports course and those taking for 2 hours, 6 hours and more in favor of the students not taking this course. There is a significant difference between the students taking the physical education and sports course for 1 hour and those taking for 2 hours, 6 hours and more in favor of the students taking this course for 1 hour. It has been determined that the bullying tendencies of the students not taking the physical education and sports course and those taking this course for 1 hour a week are lower.

A significant difference between the total bullying tendency scores of the students is out of question by the educational background of parents.

There is a significant difference between the total bullying tendency scores of students by the profession of their mothers and fathers. There is a significant difference between the students whose mothers are housewife and those whose mothers are civil servants and retired in favor of the students whose mothers are housewife. In the study of Göldağ (2015), the values of students by their mothers' professions have been found to be significant (Göldağ, 2015).

A significant difference has been established between the total bullying tendency scores of the students by the income level of their families. There is a significant difference between the students whose families earn 0-500 TL, 501-812 TL and 813-1250 TL and those with the family income of 2501 TL. Bullying tendencies of the students whose families earn $2501 \mathrm{TL}$ and more have been found to be higher.

A significant difference hasn't been established between the total bullying tendency scores of the students by the number of siblings.

There is a significant difference found between the total bullying tendency scores of the students by the type of school they study. It has been established in a study that the victim scores of the students studying in industrial vocational high school are the highest and the bullying scores of the students studying in private high schools are the highest. The students studying in Anatolian High Schools constitute the group who are exposed to and apply bullying the least (Ayas \& Pişkin, 2011).

A significant difference has been found between the total bullying tendency scores of the students by the type of school they study. There is a significant difference found between the students studying in Fine Arts High School, Girls' Vocational School and Industrial Vocational School and those studying in İmam Hatip High School, Anatolian High School and Vocational School of Health. This significant difference has also been observed between the students of Sports High School and those studying in Vocational School of Health. This same difference also exists between the students of Anatolian High School and those studying in Vocational School of Health; between the students studying in Trade Vocational High School and Science High School.

A significant difference has been found between the total bullying tendency scores of the students by the type of school they study. In a study, a significant difference has been determined between the total value scores of the students by the type of school they study (Göldağ, 2015). There is a moderately negative relation between the Total Value Scores of the students and their Total Bullying Tendency Scores. Accordingly, when the total value scores of the students increase, their bullying tendency scores decline.

\section{Conclusion and Suggestions}

The values conveyed in Physical Education and Sports Course Program are unity, peace, tolerance, love, respect, esthetic, patriotism, solidarity, respecting our sentimental and universal values, attaching importance to personal and social values, responsibility and gentlemanship. Teaching these values to the students at schools will prevent them from exhibiting bullying behaviors.

The bullying tendencies of the students taking the physical education and sports course for 6 hours and more are higher. This can derive from personal characteristics, environmental factors and family structure. However, it is meaningful that the bullying tendency of the students taking physical education and sports course more is high. 
Sports isn't only the total of physical activities. Sports contribute to the personal development of individuals, their self-realization and socialization; help them learn the value judgments of the society in which they live. It is necessary to teach students social and universal values in addition to the physical activities in physical education and sports course.

It has been put forth in various researches that the students exhibiting bullying behaviors and being exposed to such behaviors experience problems particularly in belonging and meeting the need for power. The programs considered necessary can be arranged in order to meet the basic needs of the students being in such risk group.

\section{Conflict of Interests}

The author has not declared any conflict of interests

\section{Acknowledgments}

The study is a Master Thesis which approved by Firat University Non-Interventional Research Ethics Committee Decision No: 97132852/050.01.04 and was presented in the 10th International Conference in Physical Education, Sports And Physical Therapy (ICPESPT) as a poster presentation at November 2016, Turkey.

\section{References}

Ayas, T., \& Pişkin, M. (2011). Investigation of bullying among high school students regarding sex, grade level and school type. Elementary Education Online, 10(2), 550-568.

Bektaş, M. (2007). Estimation of School Bulb in Primary School Second Grade Students (Unpublished PhD thesis). Ege University, Institute of Social Sciences, İzmir.

Bilgiç, E. (2007). Investigation of Grapevine Behaviors According to Class Variables and Atmospheric Perceptions in Elementary School (Unpublished PhD thesis). Çukurova University, Institute of Social Sciences, Adana.

Calp, Ö. (2006). Examination of the social values of senior high school students [Hatay district sample] (Unpublished master's thesis). Gazi University, Ankara.

Demirutku, K., \& Sümer, N. (2010). Measurement of Basic Values: Turkish Adaptation of the Portrait Values Questionnaire. Turkish Psychology Articles, 13(25), 17-25.

Dereli, E., \& Aypay, (2012). Predicting the Empowerment Trends of Secondary School Students and the Human Values of Collaborative Characters and Examining These Characteristics. Educational Sciences in Theory and Practice, 12(2) [Supplementary Special Issue]; Spring 1249-1270.

Dilmaç, B., Bozgeyikli, H., \& Çıkılı, Y. (2008). Investigation of Value Perceptions of Teacher Candidates in Terms of Different Variables. Values Education Journal, 6(16), 69-91.

Dölek, N. (2002). Investigation of Bullying Behaviors in Students and a Preventive Program Model (Unpublished PhD thesis). Marmara University, Institute of Educational Sciences, İstanbul.

Eşici, H. (2013). The Relationship between Solicitor Behavior and Fundamental Needs Based on Election Theory. Journal of Turkish Educational Sciences Spring, 11(2), 151-168.

Fichter, J. (2011). What is the Sociology? (Translated by Nilgün Çelebi). Ankara: Anı Publishing.

Genç, G. (2007). Peer Bullet and Management in General High School. Inönü University, Institute of Social Sciences (Unpublished $\mathrm{PhD}$ thesis). Malatya.

Göldağ, B. (2015). Education Values Through School Culture in Secondary Education Institutions (Malatya Province Example) ( $\mathrm{PhD}$ thesis, Malatya: İnönü University, Institute of Educational Sciences).

Güler, E. (2010). Investigation of Perceptions Related to Career Values of Vocational High School Students [Example of Istanbul Tuzla District] (Unpublished master's thesis). Yeditepe University, Institute of Social Sciences, İstanbul.

Hilooğlu, S., \& Önder, F. C. (2010). The Role of Social Skills and Satisfaction on Predicting Bullying in Elementary Secondary School Students. Primary Education Online, 9(3), 1159-1173. Retrieved from http://ilkogretim-online.org.tr

Kılıç, A. K., \& Kılıç, A. (2013). The Relationship between the Exposures Levels of Students in Secondary Education Institutions and Their Self-Confidence. VI. National Postgraduate Education Symposium Proceedings, Sakarya University Publications No: 95, Sakarya University Institute of Educational Sciences Publications No: 6, Sakarya. 
Özden. M. S. (2007). Comparison of Value of University Students and Neurotic Students between 20 and 24 Aged 20-24 (Unpublished master's thesis). Maltepe University, Institute of Social Sciences, İstanbul.

Rokeach, M., \& Parker, S. (1970). Values as Social Indicators of Poverty and Race Relations in America. Annals of the American Academy of Political and Social Science, 388. Political Intelligence for America's Future, 97-111. https://doi.org/10.1177/000271627038800110

Schwartz, S. H. (2009). Basic Human Values. Paper presented Cross-National Comparison Seminar on the Quality and Comparability of Measures for Constructs in Comparative Research: Methods and Applications, Bolzano (Bozen), Italy.

Tezcan, M. (1987). Culture and Personality. Ankara: Olgaç Matbaası.

Totan, T., \& Kabakçı, Ö. F. (2010). Predicting the Bullying of Social Emotional Learning Skills in Elementary Second Grade Students. Uludă̆ University Journal of Educational Faculty, 23(2), 575-600.

Totan, T., \& Yöndem, Z. D. (2007). Investigation of Bullet in Mature, Father and Peer Relations in Adolescents. Ege Education Magazine, 2(8), 53-68.

\section{Copyrights}

Copyright for this article is retained by the author(s), with first publication rights granted to the journal.

This is an open-access article distributed under the terms and conditions of the Creative Commons Attribution license (http://creativecommons.org/licenses/by/4.0/). 